\title{
THE DEVELOPMENT MODEL OF BROWN SUGAR MICRO SMALL MEDIUM ENTERPRISE IN SUMBERRINGIN VILLAGE SANAN KULON SUB-DISTRICT BLITAR REGENCY
}

\author{
Arfida Boedirochminarni \\ Economics and Business Faculty, University of Muhammadiyah Malang \\ Email: arfidaumm@gmail.com
}

\begin{abstract}
Blitar Regency is one of the areas in East Java that has become the place for the growth of the food and beverage industry, and has enormous potential. MSME (Micro, Small, Medium Enterprises) in Blitar Regency in 2011 was recorded at 18,644 units. The number then increased significantly in 2015 reaching 254,187 units. One of them is Sumberingin Micro, Small, Medium Enterprises located in the Sumberringin village, Sanan Kulon sub-district, Blitar Regency. These MSMEs seek to improve the economic sector of the region by processing natural resources into goods of the sale value, namely brown sugar. They can produce more than $12 \mathrm{~kg}$ for each production. Their profits in one production with 12 units get more than IDR 250,000. They have a lot of contributions to their village in increasing the income per capita by producing traditional product to the market and develop their local potential to compete with other modern products through social media marketing and modern market places.

Keywords: MSME, modern market, social media.
\end{abstract}

\section{INTRODUCTION}

The concerns about market economy have been frightening business people in Indonesia. It is because of the weak competitiveness of local industries which are also feared to erode the potential of local entrepreneurs and some Micro, Small and Medium Enterprises (MSMEs). In addition, Indonesia is passionate preparing the Asean Economic Community (MEA) and ACFTA.
MSMEs are expected to be able to survive in their own country, as well as to compete in the global market. The development and empowerment of MSMEs are a strategic step, moreover MSMEs have a large role in increasing employment (Sabirin, 2016).

The total workers in Indonesia which reached 110 million people, around 107 million are included in the structure of MSMEs. This means the 
proportion of people working as MSMEs reached around 97.3 percent in which only 2.7 percent or about 3 million who work for large corporations. The MSME categories are farmers, fishermen, warteg (food stall with cheap food) sellers, market traders, scavengers, construction workers, and motorcycle taxi drivers. They are micro entrepreneurs who work in the informal sector. People who open shops, factories, small to medium scale processing industries are also included in MSME group. Some small and medium businesses have been in the form of business entities, such as cooperatives, foundations, commanditaire vennootschap $(\mathrm{CV})$ or even limited companies (PT). If it is in the form of a corporation, it is categorized as a formal sector (Marta, 2016).

Related to this, the data collection of MSME workers in Blitar Regency is still not up to date. Based on the documents of Blitar Regency in 2017 (BPS Blitar Regency, 2017), the total formal and informal small-scale industrial workers in Blitar Regency in 2013 were 28,627 people. Meanwhile, the number of workers regarding the brown sugar industry (IKM) centers was 25,763 people. Based on the 2015 Regional Statistics of Blitar Regency, it was found that the number of people working in Blitar Regency in 2013 was 593,213 people (BPS Blitar District, 2015). This means the portion of people working in small industries in Blitar in 2013 was about 4.83 percent. However, 90 percent of the total small industry workers are working in the brown sugar IKM center.

MSME is not only creating jobs but also playing a role in economic growth in Indonesia. The contribution of the MSME sector to gross domestic product (GDP) increased from 57.84 percent to 60.34 percent in the last five years (2011-2015). Uptake of labor in this sector also increased from 96.99 percent to 97.22 percent in the same period. Although the indicator of contribution to GDP formation and labor absorption is increasing, the access to the MSME sector to the 
supply of global production is very small. The contribution of MSME in Indonesia to the global supply is only 0.8 percent. In ASEAN, the contribution of Indonesian MSME to the global production supply is only slightly higher compared to Brunei, Laos, Myanmar and Cambodia. The highest contribution of the MSME sector to the global production supply reached 2.7 percent. In fact, ASEAN contributed 9.3 percent to the global production supply in the 2009-2013 period. While the contribution of the MSME sector to Indonesia's exports in 2015 was only 15.8 percent. It is much smaller than the countries in Southeast Asia. The contribution of the Thai MSME sector to exports was 29.5 percent and the Philippines was 20 percent. At the global level, the contribution of the German MSME sector to exports reached 55.9 percent and Japan was about 53.8 percent (Ministry of Industry, 2016).

Therefore, based on the Government Agency Performance Report (LKJIP) document in 2015, it was found that the economy of Blitar Regency had been weak in 2014 (5.02 percent), but in 2015 it grew faster which reached 5.06 percent though the increase was not too significant. As for the growth of the Blitar Regency GRDP Sector in 2015 showed that the categories of Large Trade and Retail; Car and Motorcycle Repair had the highest economic growth. However, if it is examined more closely, the economic growth of Blitar Regency in 2015 was 5.06 percent, mainly obtained from the categories of Agriculture, Forestry and Fisheries, which is about 1.30 percent, but in the category of Large Trade and Retail contributed to 1, 21 percent of the total growth (Blitar Regency Government, 2016).

MSME also has a contribution to GDP by 4,303 trillion/year. In Indonesia, currently, the number of micro-enterprises reaches 98.82 percent and small businesses reaches 1.09 percent only. By having a target of increasing MSME by 20 percent, it is not surprisingly that MSME has become a priority at every planning 
stage of development especially organized by two ministries, namely Ministry of Industry and Ministry of Cooperatives and MSME (Sabirin, 2016).

Regarding to this condition, based on Government Agency Performance Report (LKJIP) document in 2015, it was known that Blitar Regency still has an agrarian pattern until 2015 in terms of economic structure. This is reflected in the large share of agricultural, forestry and fisheries business field categories which contributed $35.89 \%$ to the Blitar Regency GRDP in that year. The next category that is equally important in the economy of Blitar Regency is Large Trade and Retail; Car and Motorcycle Repair, which contributes about $17.01 \%$ to total GRDP. Over the years the contribution of Agriculture, Forestry and Fisheries has increased. This is a good news because after all the agricultural business fields became the hopes for almost a portion of the Blitar Regency population. (Blitar Regency Government, 2016). Besides MSME is a small-scale business category that is assured to be able to contribute to the Indonesian economy especially during the economic crisis that occurred in the period of 1998 up to 2000s. MSME is considered capable of surviving a crisis when dozens of large companies are experienced bankruptcy (Manurung, 2008).

Related to this, MSME in Blitar Regency were able to survive during the monetary crisis in 1998. This was stated in the Regional Regulation of Blitar Regency Number 6 of 2012 concerning Empowerment of Cooperatives and Micro, Small, and Medium Enterprises. The general explanation states that MSME as one of the dominant economic actors in the business world have been able to prove themselves free from the economic crisis, and can even assist the government in strengthening the national economy after the crisis happened. Along with the government's efforts to empower the people's economy, the MSME empowerment program as a business actor is 
necessary to be continually encouraged and improved because it also contributes to supporting the national economic business that has a very important position, potential and role. Therefore, MSME activities should further expand employment, provide economic services, and increase people's income. (Blitar Regency Government, 2012). One of the MSME centers of food and beverages categories especially brown sugar in Blitar Regency is located in Sumberingin Village, Sanankulon District. In Sumberingin Village, there is a lot of brown sugar MSME that are engaged in the processing industry (processing basic materials into goods) but are included in home industry group (BPS Blitar Regency, 2016).

As one of the centers of brown sugar processing industry in Blitar Regency, MSME in Sumberingin Village produces several brown sugar products in various forms (shells, granules or powders, coins, etc.). This small and medium business is dominated by home industries that are engaged in the business of processing raw materials into goods. The brown sugar business continues to develop along with the increase in the demand for these products. On the other hand, they face limited raw materials. Dealing with this, MSME has to buy raw materials from outside Blitar Regency (Soerabaia Newsweek, 2016). Meanwhile, other problems faced are the high prices of raw materials which are increasing, such as fuel and basic raw materials. Some problems related to how to meet consumer needs amid the threat of limited raw materials and high prices of raw materials make all brown sugar MSME entrepreneurs in Sumberingin Village have to think creatively to stick to the principles of development and productivity of brown sugar business. This is one of the serious concerns of any brown sugar MSME entrepreneur in Sumberingin Village, Sanankulon District, Blitar Regency (Pojok Pitu, 2015).

This study aims to find out the profile of brown sugar MSME in Sumberingin Village, Sanankulon 
District, Blitar Regency and analyze the model of development of brown sugar MSME in Sumberingin Village, Sanankulon District, Blitar Regency in developing its business.

Harahap (2007) defined income as "gross increase in the asset and gross decrease in the obligation that valued based on the principles of accounting derived from the activity of gaining profit". The same notion was also stated by Nafarin (2004) "Income is a gross increase in the owner's equity that generated from the selling of goods, servicing customers or clients, property rental, loan, business activities, and profession aiming to generate income".

According to Sukiro (2004), income is basically a reward or recompensation received by the production factors for the sacrifice given during the production process. The land factor will be rewarded with land rent; the labor factor will gain salary; the capital factor will obtain capital interest, and the entrepreneurship factor will gain profit. The personal income comprises all kinds of income including one gained without contributing any activity that received by a resident of a country. One of the ways of improving a region's income and economy is developing the Small and Medium Enterprises (SMEs).

Sukimo (2004) stated that SMEs are small start-up capital or assets with limited labors determined by the government or institution for specific purposes. However, there must be problems encountered during the production and distribution processes, such as unclear policies, poor human resources management and organization, raw material issues, unorganized financial reports (or even unavailability of a financial report), relatively low-quality labor, and lowquality raw materials (Kuncoro, 2004).

By identifying the strengths and weaknesses of each small business, the best strategy for developing it is by taking advantage of an opportunity and solving the challenges encountered in the business world. The opportunity will induce the rapid development and 
growth of the small enterprises, while the challenges are best solved systematically, effectively, efficiently, and optimally (Kuncoro, 2004).

\section{RESEARCH METHODS}

This study was conducted in Sumberingin Village, Sanankulon Subdistrict, Blitar Regency. It was selected since the sub-district is a central of brown sugar SMEs in Blitar with a total of 391 units of enterprises (Central Bureau of Statistics of Blitar Regency, 2016). It is a descriptive study.

In this study, the researcher describes the development of SMEs in the center of the brown sugar industry in Sumberingin Village, Sanankulon Sub-district, Blitar Regency. This study used the quantitative approach i.e. answering the statement problem based on calculation (numbers) which data were obtained from the respondents through distributed questionnaires.

The population of this study is all the 168 brown sugar SMEs in Sumberingin Village, Sanankulon Subdistrict, Blitar Regency (Central Bureau of Statistics of Blitar Regency, 2015). According to Arikunto (2010), in sampling, if the subjects are less than 100 , it is better to use all of them; and if the subjects are more than 100, 10-15\% or $20-25 \%$ of them can be deployed. Therefore, since the total number of the SMEs was $168,15 \%$ of it (25 SMEs) was used as a sample.

The sampling techniques used was the accidental one. A sampling based on the coincidence in which the researcher finds suitable samples that meet the criteria during the research. The researcher searched for the owners of the SMEs that have been operating since 2016. Thus, the questionnaires were given to them based on the criteria.

The data collected in this study were classified into two: the primary data is the main data in form of filled questionnaires that were obtained from the owners of the SMEs to answer the statement of problems, and the secondary data is the additional data in form of general information about Sumberingin Village, Sanankulon Sub- 
district, Blitar Regency and the documentation of the researcher on the site.

\section{RESULT AND DISCUSSIONS}

The result showed that the males dominate the operation of MSMEs for brown sugar where the proportion number of male and female is 15 and 10 respectively. The majority of entrepreneurs who run the business aged over 50 years old is nine persons. The next group is aged $45-49$ and 35 39 , each of which has four people running brown sugar business. At the age group of 40-44 and 30-34, there are three people who run these MSMEs, whereas in the age range of 25-29 there are only two people who run the MSMEs.

The analysis of business duration for brown sugar MSMEs indicated that there are 15 business units has been operating since 15 years ago with the proportion of 60 percent of the total existing MSMEs. Meanwhile, there are 7 business units has been operating since the 10-14 years. There are 12 percent or 3 units of all MSMEs that run their businesses within a period of 5-9 years. MSMEs is able to produce more than $12 \mathrm{~kg}$ in one production period. Meanwhile, there are 8 business units that could produce $6-11 \mathrm{~kg}$ in one production period. Moreover, 5 business units could produce $1-5 \mathrm{~kg}$. 12 MSMEs or 48 percent have the outcome of production cost more than Rp 150.000,00 in one production period. On the other hand, the second proportion with the total of MSMEs is 32 percent or 8 unit business spends the production cost in the range of $\mathrm{Rp}$ $100.000,00$ - Rp 149.000,00 in one production period.

The other 5 units or 20 percent spend Rp 50.000,00 - Rp 99.000,00 in one production period. Based on income analysis in one production there are 12 units that get more than $\mathrm{Rp}$ $250.000,00$ in one production, while in the income range of $\operatorname{Rp} 200.000,00-$ Rp 249.000 which are 5 business units that get it in one production. There are 3 business units that earn $\mathrm{Rp}$ $150.000,00$ - Rp 199.000,00 in one 
production, while in the income range of Rp 100.000,00 - Rp 149.000,00 which are 2 business units. In the lowest income range $\mathrm{Rp} 50.000,00-\mathrm{Rp}$ $99.000,00$ there are 3 business units that get it in one production.

\section{Finance}

The value of Cronbach's Alpha from reliability test is $-0.088<-0.217$. It means that finance instrument $(\mathrm{X} 1)$ in this study could be used for an effect in the strategy of brown sugar MSMEs development. However, the effect does not show a significant increase based on the results of field notes from 25 participants. They actually do not use the credit offers to expand their business. The participants tend to prioritize the consumptive business.

The most influential variable from 9 items for finance variable (X1) based on reliability test is VN4 with the value of 0,358 . VN4 asked about when the business is starting and whether they loan from external sources or not. Based on the test, it is known that the participant needs external funding to expand their business. However, the funding is not used properly.

\section{Production}

The value of Cronbach's Alpha from reliability test is $-0.087<-0.064$. It means that the production of brown sugar (X2) in this study could be used for low effect in the strategy of brown sugar MSMEs development. The higher production level of brown sugar therefore business capital is not necessarily back due to the income could not fulfill the initial capital.

The most influential variable from 9 items for brown sugar production variable (X2) based on reliability test is VN8 with the value of -0.07 . It means that the participant can yield the capital back. VN8 asked about the capital will be back or not during running the business.

\section{Business/Marketing Development}

The value of Cronbach's Alpha from reliability test is $-0.009<0.03$. It shows that the instrument of Business/ Marketing Development (X3) has a medium effect which means that the 
brown sugar business development must consider new marketplace for their product besides having a homebased business. Other place such as the nearest local market or to have sold it online may develop their business.

The most influential variable from 5 items on the variable of Business/Marketing Development (X3) based on reliability test is $\mathrm{VN} 2$ with its value of 0.094 . VN2 asked about they sell their brown sugar to the nearest local market or not.The achieved value idicate that the best business development is by selling the brown sugar to the nearest market.

\section{Business Development in Funding}

The value of Cronbach's Alpha from reliability test is $0.257>0.143$. It shows that the instrument of Business Development in Funding (X4) has a medium effect. The medium effect means that if the Brown Sugar SME wants to produce a higher amount of product, it must add the capital in
Sumberingin village through Small Business Credit (KUK) and People Business Credit (KUR) as long as the incentive is to develop the business.

The most influential variable from 8 items for business in funding variable (X4) based on reliability test is VN8 with the value of 0.374 . VN8 described about the increasing of their sales due to capital addition through Micro Business Credit and People's Business Credit. The achieved value indicates that the brown sugar Small and Micro Business Enterprise can increase their production through capital assistance of Micro Business Credit and People's Business Credit at Sumberingin village.

As a further explanation, below is the model of marketing development model of Small and Micro Business Enterprise of brown sugar at Sumberingin village, sub district of Sanankulon, Blitar city: 
Figure 1. Marketing Development Model of Small and Micro Business Enterprise of Brown Sugar

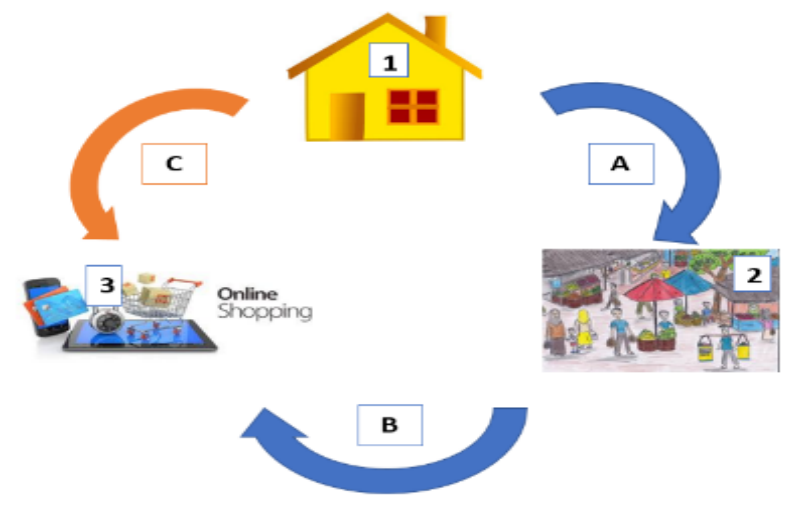

Source : Processed Application, 2018

The figure of Production House (1): Small and Micro Business Enterprise will receive a very cheap benefit if they only depend on in-house sale for collectors. Figure of Traditional Market L the Small and Micro Business Enterprise (2) will receive a fair benefit in accordance with average market price if they sell their product in nearby market. Figure of Online Market (3): Small and Micro Business Enterprise will have faster and more practical selling activity if they use the online marketing.

\section{CONCLUSION}

The Small and Micro Business Enterprise of Sumberingin is located at
Sumberingin village, the sub-district of Sanan Kulon, Blitar regency. This business unit attempts to increase the regional economic sector through processing the natural resources into something with sales value for brown sugar product. To increase the Small and Micro Business Enterprise on brown sugar, the producer must have a certain business strategy that is to produce at least $13.92 \mathrm{~kg}$ with interesting package. The next step of this business development model is by selling the product to the nearest market and through online marketing to increase the productivity and broaden the market target. The online marketing can be in the form of social media usage 
or through other form of online media such as website and online shop.

\section{REFERENCES}

Arikunto, Suharsimi. 2010. Prosedur Penelitian: Suatu Pendekatan Praktek. Jakarta: Rineka Cipta.

Boedirachminarni, Arfida. 2009. Membangun penduduk sadar lingkungan melalui pembentukan forum guru pemerhati lingkungan di Malang Raya. Research Report of DPPM UMM.

Boedirachminarni, Arfida and Priananta, Wahyu. 2009. Pengembangan kampus Universitas Muhammadiyah Malang sebagai kunjungan wisata pendidikan lingkungan hidup. Research Report DPPM UMM.

Boedirachminarni, Arfida. 2013. Pendidikan dan Wisata di Kota Malang. Research Report of DPPM UMM

Boedirachminarni, Arfida. 2017. Model Pengembangan Kampung Santren Gadingkasri. Report of DPPM UMM

BPS of Blitar regency. 2015. Statistik Daerah Kabupaten Blitar 2015. Blitar: BPS Regency of Blitar.

BPS of Blitar regency. 2016. Kecamatan Sanankulon Dalam Angka 2016. Blitar: BPS Regency of Blitar.

BPS of Blitar regency. 2017. Kabupaten Blitar Dalam Angka 2017. Blitar: BPS Regency of Blitar.
Harahap, Sofyan Syafri. 2007. Analisa Kritis Atas Laporan Keuangan. Jakarta: Raja Grafindo Persada.

Hartono, S., Anash, Masyhuri, Jangkung, H. M. 2015. Tinjauan Teoritis dan Empiris Pengembangan, Risiko, dan Perilaku Risiko Usaha Tani Serta Implikasinya Dalam Upaya Pencapaian Swasembada Pangan. Jurnal Forum Agro Ekonomi, Vol. 33 No. 2: 81-94.

Huda, Nurul and Mustafa Edwin Nasution. 2009. Current Issues Lembaga Keuangan Syari'ah. Jakarta: Kencana.

Kemenperin. 2016. Kontribusi UMKM Naik,

http://www.kemenperin.go.id/artikel/

14200/Kontribusi-UMKM-Naik

Kuncoro, Mudrajad. 2004. Ekonomi Pembangunan: Teori, Masalah, dan Kebijakan. Yogyakarta: AMP YKPN.

Kuncoro, $\quad 2013$. Metode Riset untuk Bisnis dan Ekonomi. Jakarta: Erlangga.

Kusnadi. 2000. Akuntansi Keuangan Menengah (Intermediate): Prinsip, Prosedur \& Metode. Malang: Universitas Brawijaya.

Mahabirama, A.K., Kuswanti, H., Daryanto, S., and Winandi, R. 2013. Analisis Pengembangan dan Pendapatan Usahatani Kedelai di Kabupaten Garut Provinsi Jawa Barat. Jurnal Aplikasi Manajemen, Vol. 11, No. 2, Juni: 197-206.

Makmur. 2016. Analisis Biaya Produksi dan Titik Impas Usaha Kecil Pembuatan Sari Jahe Instan. 
Jurnal Ilmiah Cano Ekonomos, Vol. 5, No. 1, Januari: 55-62.

Marta, Muhammad Fajar. 2016. UMKM dan Ketidakberdayaannya, http://bisniskeuangan.kompas.co $\mathrm{m} / \mathrm{read} / 2016 / 06 / 09 / 084045026 / \mathrm{U}$ MKM.dan.ketidakberdayaannya

McEachern, William A.J. 2001. Pengantar Ekonomi Mikro. Jakarta: Salemba Empat.

Miller, Roger Le Rey and Roger E. Meiners. 2000. Teori Mikroekonomi Intermediate. Jakarta: Raja Grafindo Persada.

Nafarin, M. 2004. Penganggaran Perusahaan. Jakarta: Salemba Empat.

Nurlela. 2015. Analisis Pengembangan dan Produktivtas Usaha Kecil Menengah di Kota Sorong (Kasus Usaha Kripik). Jurnal Agroforestri, Vol. X, No. 3, September: 247-254.

Pemkab Blitar. 2012. Peraturan Daerah Kabupaten Blitar Nomor 6 Tahun 2012 Tentang Pemberdayaan Koperasi dan Usaha Mikro, Kecil, Menengah. Blitar: Regional Government of Blitar.

Pemkab Blitar. 2016. Laporan Kinerja Instansi Pemerintah (LKJIP) Tahun 2015. Blitar: Regional Government of Blitar.

Pemkab Blitar. 2016. Perda No. 4 Tahun 2016 tentang RPJMD (Rencana Pembangunan Jangka Menengah Daerah) Tahun 20162021. Blitar: Regional Government of Blitar.

Pojok Pitu. 2015. Perajin Gula Kelapa Terancam

Bangkrut, http://www.pojokpitu.

com/baca.php?idurut $=527 \& \&$ top

$=1 \& \& \mathrm{ktg}=$ Jatim\&\&keyrbk=Eko nomi\%20Dan\%20Bisnis\&\&keyj $\mathrm{dl}=$ Perajin

Pratomo, Tiktik Sartika dan Abd. Rachman Soejodono. 2002. Ekonomi Skala Kecil/Menengah \& Koperasi. Jakarta: Ghalia Indonesia.

Sabirin. 2016. Era Pasar Bebas Usaha Mikro Kecil Menengah (UMKM) Indonesia Siap atau Tidak? http://www.kompasiana.com/sab irinsaiga/era-pasar-bebas-usahamikro-kecil-menengah-UMKMindonesia-siap-atautidak_571f8ae5c322bd7408cd1b 24

Soekartawi. 2003. Teori Ekonomi Produksi dengan Pokok Bahasan Analisis Fungsi Cobb-Douglas. Jakarta: Raja Grafindo Persada.

Soemarso. 2005. Akuntansi: Suatu Pengantar. Jakarta: Salemba Empat.

Soerabaia Newsweek. 2016. Kecamatan Sanankulon Kab Blitar Sentra Industri Gula Kelapa Jatim, http://www.surabayanewsweek.c om/2016/11/kecamatan sanankulon-kab-blitarsentra.html? $\mathrm{m}=0$

Soeratno. 2000. Ekonomi Mikro: Pengantar. Yogyakarta: STIE YKPN.

Sudarsono,

Heri. 2007. Bank dan Lembaga Keuangan Syariah. Yogyakarta: Ekonisia-Kampus FE UII. 
Sukirno, Sadono. 2004. Makro Ekonomi: Teori Pengantar. Jakarta: Raja Grafindo Persada. Sundari, Mei Tri. 2011. Analisis Biaya dan Pendapatan Usaha Tani Wortel di Kabupaten Karanganyar. Jurnal SEPA (Sosial, Ekonomi, Pertanian, Agribisnis), Vol. 7, No. 2, Pebruari: 119-126.

Tambunan, Tulus, T.H. 2002. Usaha Kecil dan Menengah di
Indonesia: Beberapa Isu Penting. Jakarta: Salemba Empat.

Widodo, Hartono. 2000. PAS (Pedoman Akuntansi Syari'ah): Panduan Praktis Operasional BMT. Bandung: Mizan.

Wismiarsi, T., Shihab, W.S., Adidarma, W. 2008. Hambatan Ekspor UKM Indonesia. Jakarta: Penerbit Buku Kompas. 